KONSTAN
JURNAL FISIKA DAN PENDIDIKAN FISIKA
Volume 4, Nomor 1, Juni 2019
$\begin{array}{r}\text { E-ISSN : 2460-9129 dan P-ISSN : 2460-9110 } \\ \text { http://jurnalkonstan.ac.id/index.php/jurnal }\end{array}$

\title{
PENGARUH MODEL PEMBELAJARAN GENERATIF DENGAN GUIDED TEACHING TECHNIC TERHADAP KEMAMPUAN PEMECAHAN MASALAH FISIKA KELAS XI
}

\author{
Ziadatul Fatimah $^{1 *}$, Hikmawati $^{1}$, Wahyudi $^{1}$ \\ ${ }^{1}$ Fakultas Keguruan dan Ilmu Pengetahuan, Universitas Mataram, Jln. Majapahit No. 62, \\ Mataram, NTB, Indonesia
}

\section{Info Artikel}

Sejarah Artikel:

Diterima Desember 2018

Disetujui Juni 2019

Dipublikasikan Juni 2019

\section{Kata Kunci:}

Model Generatif,

Kemampuan Pemecahan

Masalah

\begin{abstract}
Abstrak
Penelitian ini bertujuan untuk mengetahui pengaruh model pembelajaran generatif dengan guided teaching technic terhadap kemampuan pemecahan masalah fisika SMA kelas XI. Jenis penelitian ini adalah kuasi eksperimen dengan desain penelitian non-equivalent control group design. Populasi penelitian ini adalah seluruh peserta didik kelas XI MIA MA Al-Falah Pancordao Lombok Tengah. Pengambilan sampel menggunakan teknik sampling jenuh sehingga diperoleh kelas XI MIA 1 sebagai kelas eksperimen dan kelas XI MIA 2 sebagai kelas kontrol. Kelas eksperimen diberikan perlakuan dengan menggunakan model pembelajaran generatif dengan guided teaching technic, sedangkan kelas kontrol diberi perlakuan menggunakan model pembelajaran konvensional. Data kemampuan pemecahan masalah diperolah dengan menggunakan tes uraian berjumlah 6 soal yang telah diuji validitasnya sehingga hasil tes akhir kemampuan pemecahan masalah diperoleh rata-rata kelas kontrol 45.91 dan 52.65 untuk kelas eksperimen. Hipotesis penelitian diuji dengan uji-t polled varians diperoleh bahwa nilai t-hitung sebesar 2.18 dan nilai t-tabel sebesar 2.02 pada taraf signifikan $5 \%$ yang berarti bahwa H0 ditolak dan Ha di terima. Berdasarkan hasil penelitian, dapat disimpulkan bahwa terdapat pengaruh model pembelajaran generatif dengan guided teaching technic terhadap kemampuan pemecahan masalah fisika kelas XI.
\end{abstract}

(C) 2019 Universitas Islam Negeri Mataram

\footnotetext{
* Corresponding Author: Ziadatulfatimah96@gmail.com
}

Alamat korespodensi:

Gedung Pasca Sarjana Lantai 3 Kampus 2 UIN Mataram, Jl. Gajah Mada 100 Jempong Mataram, Indonesia

Email: jurnalkonstan@uinmataram.ac.id 


\section{PENDAHULUAN}

Fisika merupakan bagian dari sains yang mempelajari gejala alam yang tidak hidup atau materi dalam lingkungan hidup ruang dan waktu, serta semua interaksi yang menyertainya. Fisika sering disebut sebagai ilmu yang paling mendasar karna setiap ilmu alam lainnya mempelajari jenis sistem materi tertentu yang mematuhi hukum fisika. Beberapa konsep abstrak yang terdapat dalam pembelajaran fisika, menimbulkan kesulitan dalam memahami suatu materi. Sehingga peserta didik sering beranggapan bahwa fisika adalah mata pelajaran yang sulit dan cenderung mempelajari tentang rumus. Minat peserta didik yang kurang dalam mempelajari fisika menyebabkan rendahnya hasil belajar fisika peserta didik.

Berdasarkan hasil observasi melalui wawancara dengan guru mata pelajaran fisika dan peserta didik MA Al-Falah Pancordao, menunjukkan bahwa proses pembelajaran fisika yang berlangsung masih didominasi oleh pembelajaran yang kurang melibatkan peran aktif peserta didik. Pembelajaran yang digunakan masih berpusat pada guru dan sebatas transfer informasi, terlebih pada materi berupa teori dan persamaan matematis. Pembelajaran yang hanya mentransfer informasi dapat mengakibatkan peserta didik menjadi pasif dan proses kegiatan pembelajaran yang pasif mengakibatkan peserta didik kurang memahami konsep dalam menerima materi sehingga mempengaruhi rendahnya hasil belajar fisika.

Rendahnya hasil belajar fisika kelas XI MA Al-Falah Pancordao didukung oleh nilai rata-rata ujian tengah semester mata pelajaran fisika semester I tahun ajaran 2017/2018. Nilai rata-rata ujian tengah semester memiliki rentang nilai yang kecil dengan Kriteria Ketuntasan Minimum (KKM). Rentang tersebut menunjukkan bahwa hasil belajar yang diperoleh masih tergolong rendah. Hasil belajar fisika yang demikian terjadi karena dalam kegiatan pembelajaran peserta didik masih pasif yang mengakibatkan kurangnya kemampuan pemecahan masalah fisika. Peserta didik masih sulit memecahkan masalah dalam proses pembelajaran karena belum adanya keselarasan dan koneksi antara pengetahuan awal yang dimiliki peserta didik dengan pengetahuan baru yang didapat dari kegiatan pembelajaran. Sehingga diperlukan suatu pengorganisasian awal dan bantuan secara sistematik yang dapat menghubungkan kedua pengetahuan tersebut.

Perbaikan dalam kegiatan pembelajaran perlu dilakukan agar kemampuan pemecahan masalah peserta didik dapat meningkat. Salah satu alternatif pemecah masalahnya adalah pemilihan model pembelajaran yang dapat mendukung tercapainya tujuan mata pelajaran fisika adalah model pembelajaran yang berlandaskan paham konstruktivisme. Menurut Zulkarnain et al. (2014) menyatakan bahwa pembelajaran dengan dasar pandangan konstruktivisme dapat dilaksanakan dengan menggunakan berbagai macam model pembelajaran, salah satu model yang digunakan adalah dengan model pembelajaran generative [1]. Wena (2014) membagi tahapan-tahapan model pembelajaran generatif menjadi empat tahap diantaranya: (1) Pendahuluan atau disebut tahapan eksplorasi; (2) Pemfokusan; (3) Tantangan atau tahapan pengenalan konsep; dan (4) Penerapan konsep. Model pembelajaran generatif ini dapat dilakukan peserta didik secara berkelompok yang terdiri atas 4 sampai 6 orang [2]. 
Peserta didik akan lebih mudah dalam memecahkan masalah selain dengan menerapkan model pembelajaran generatif menggunakan bantuan guided teaching technic. Menurut Gumilar (2005), guided teaching technic merupakan suatu pembelajaran aktif yaitu kegiatan belajar mengajar dengan cara guru menanyakan satu atau lebih pertanyaan untuk membuka pengetahuan mata pelajaran atau mendapatkan hipotesis atau kesimpulan [3]. Berdasarkan penelitian yang telah dilakukan oleh Tuada (2017) telah terbukti bahwa pembelajaran fisika dengan menggunakan guided teaching technic berpengaruh positif terhadap kemampuan pemecahan masalah [4]. Teknik ini juga berpengaruh dalam keaktifan peserta didik di dalam kelas yang diharapkan mampu mengembangkan kemampuan pemecahan masalah fisika peserta didik.

Berdasarkan uraian diatas peneliti tertarik untuk melakukan penelitian dengan menggunakan model pembelajaran generatif dengan guided teaching technic di MA Al-Falah Pancordao Lombok Tengah. Hal tersebut didukung dari hasil observasi yang di lakukan kepada peseta didik dan guru yang mengajar mata pelajaran fisika. Kemampuan pemecahan masalah peserta didik masih kurang sehingga mempengaruhi hasil belajar fisika peserta didik. Peneliti berharap penggunaan model pembelajaran generatif dengan guided teaching technic mampu meningkatkan kemampuan pemecahan masalah peserta didik pada pembelajaran fisika di tingkat sekolah menengah atas. Penelitian ini bertujuan untuk mengetahui pengaruh model pembelajaran generatif dengan guided teaching technic terhadap kemampuan pemecahan masalah fisika kelas XI.

\section{METODE PENELITIAN}

Jenis penelitian yang digunakan adalah kuasi eksperimen. Pada kuasi eksperimen, peneliti tidak memiliki kekuasaan untuk memanipulasi subjek, artinya random kelompok biasanya dipakai sebagai dasar untuk menetapkan sebagai kelompok perlakuan dan kontrol [5]. Penelitian kuasi eksperimen bertujuan untuk mengetahui ada tidaknya pengaruh variabel tertentu dengan variabel lain dalam kondisi dikendalikan.

Variabel penelitian adalah segala sesuatu yang berbentuk apa saja yang ditetapkan oleh peneliti untuk dipelajari, sehingga diperoleh informasi tentang hal tersebut, kemudian ditarik kesimpulan [6]. Pada penelitian ini yang menjadi variabel bebas adalah model pembelajaran generatif dengan guided teaching technic, variabel terikat adalah kemampuan pemecahan masalah, variabel kontrol adalah materi ajar yang diajarkan, guru yang mengajar, dan instrumen penilaian pada kelas eksperimen dan kontrol.

Penelitian ini menggunakan non-equivalent control group design [7]. Sampel penelitian dibagi menjadi dua kelompok yaitu kelompok eksperimen dan kelompok kontrol. Kelompok eksperimen diberikan perlakuan dengan menggunakan model pembelajaran generatif dengan guided teaching technic sedangkan kelas kontrol menggunakan pembelajaran konvensional yang sudah di terapkan di sekolah. Pada pembelajaran konvensional biasanya menggunakan metode ceramah sebagai alat komunikasi antara guru dan siswa. 
Penelitian ini dilakukan pada tahun ajaran 2017/2018, mulai bulan September hingga November 2018 dari penetapan judul penelitian hingga ujian. Untuk pengambilan data penelitian dilakukan pada bulan April hingga bulan Mei 2018. Tempat penelitian ini dilakukan di MA Al-Falah Pancordao Lombok Tengah.

Populasi dan sampel pada penelitian ini adalah sebagai berikut. Populasi merujuk pada keseluruhan kelompok dari mana sampel-sampel diambil yang merupakan keseluruhan dari objek yang menjadi perhatian dan kajian dalam penelitian Setyosari [5]. Populasi pada penelitian ini adalah seluruh kelas XI MA Al-Falah Pancordao Lombok Tengah 2017/2018.

Sampel penelitian mencerminkan dan menentukan seberapa jauh sampel tersebut bermanfaat dalam membuat kesimpulan penelitian [9]. Teknik pengambilan sampel yakni teknik sampling jenuh. Teknik sampling jenuh adalah teknik penentuan sampel bila semua anggota populasi digunakan sebagai sampel [10]. Dalam peneliti ini hanya terdapat dua kelas sebagai kelas eksperimen dan kelas kontrol yang akan di jadikan penelitian dan pengambilan data.

Penelitian ini dilakukan dalam tiga tahap yakni tahap persiapan, tahap pelaksanaan, dan tahap akhir. Instrumen penelitian merupakan suatu alat yang digunakan untuk mengukur fenomena alam maupun sosial yang diamati [11]. Instrumen tes kemampuan pemecahan masalah yang digunakan berupa soal uraian sebanyak 6 soal yang meliputi indikator kemampuan pemecahan masalah. Instrumen tes kemampuan pemecahan masalah sebelum digunakan dalam penelitian juga harus memenuhi beberapa syarat yaitu validitas, reliabilitas, tingkat kesukaran, dan daya beda [12].

Analisis data yang digunakan pada penelitian ini adalah sebagai berikut. Sampel yang digunakan dalam penelitian ini adalah Kelas XI MIA 1 dan Kelas XI MIA 2. Data yang diambil dari kedua kelompok sampel berupa data awal (tes awal kemampuan pemecahan masalah) dan data akhir (tes akhir kemampuan pemecahan masalah) sesuai dengan desain penelitian yang digunakan. Data awal dan akhir kemudian diuji dengan uji persyaratan analisis data.

Uji persyaratan analisis data yang digunakan pada penelitian ini adalah sebagai berikut. Uji homogenitas merupakan uji yang dilakukan terhadap data awal peserta didik, yakni berupa tes awal. Pada penelitian ini, uji homogenitas sampel dengan menggunakan uji varians atau uji-F [13]. Uji Normalitas adalah sebuah uji yang dilakukan dengan tujuan untuk menilai data pada sebuah kelompok data atau variabel. Uji Normalitas berguna untuk menentukan data yang telah dikumpulkan berdistribusi normal atau diambil dari populasi normal. Uji normalitas dicari dengan menggunakan rumus Uji Chi Kuadrat. Hipotesis-hipotesis pada penelitian ini adalah sebagai berikut.

$\mathrm{H}_{\mathrm{a}}$ : Ada pengaruh model pembelajaran generatif dengan guided teaching technic terhadap kemampuan pemecahan masalah fisika SMA kelas XI.

$\mathrm{H}_{0}$ : Tidak ada pengaruh model pembelajaran generatif dengan guided teaching technic terhadap kemampuan pemecahan masalah fisika SMA kelas XI.

Uji hipotesis merupakan tahap akhir analisis data dalam suatu penelitian. Hipotesis penelitian dapat diuji menggunakan uji statistik parametrik. Uji statistik yang digunakan dipengaruhi normalitas data akhir kedua kelas. Untuk mengetahui 
pengaruh model pembelajaran generatif dengan guided teaching technic terhadap kemampuan pemecahan masalah digunakan uji-t satu pihak.

\section{HASIL DAN PEMBAHASAN}

\section{A. Hasil Penelitian}

Hasil penelitian ini terdiri dari hasil uji instrumen dan analisis kemampuan pemecahan masalah pada saat tes awal dan tes akhir pembelajaran. Data kemampuan pemecahan masalah dianalisis menggunakan uji homogenitas, uji normalitas, dan uji hipotesis yang terdiri dari uji independent sample t-test. Uji instrumen telah dilakukan pada kelas XI MIPA 1 di SMA AL-Azhar NW Kayangan pada tanggal 7 April 2018 yang diikuti sebanyak 22 peserta didik. Uji instrumen yang telah dilakukan berupa uji validitas, reliabilitas dan daya beda pada soal uraian. Instrumen soal uraian yang diuji sebanyak 6 soal yang mewakili indikator kemampuan pemecahan masalah. Berdasarkan hasil analisis validitas item soal didapatkan semua item soal uraian dapat dikatakan valid dan dapat digunakan untuk tes awal dan tes akhir dalam penelitian karena nilai $r_{X Y}$ lebih besar daripada $r_{\text {tabel }}$. Berdasarkan hasil analisis reliabilitas item soal didapatkan bahwa semua item soal termasuk ke dalam kategori reliabel, karena nilai $r_{11}$ lebih besar dari $r_{\text {tabel }}$. Berdasarkan hasil analisis daya beda item soal didapatkan 2 item soal termasuk dalam kategori jelek, 1 item soal termasuk ke dalam kategori cukup, 2 item soal termasuk ke dalam kategori baik, dan 1 item soal termasuk ke dalam kategori sangat baik.

Data hasil tes awal dan tes akhir kemampuan pemecahan masalah fisika peserta didik untuk kelas kontrol dan kelas eksperimen dapat dilihat pada Tabel 1.

Tabel 1. Hasil Tes Awal dan Tes Akhir Kemampuan Pemecahan Masalah

\begin{tabular}{lllllll} 
Kelas & Tes & Jumlah & $\begin{array}{l}\text { Nilai } \\
\text { Terendah }\end{array}$ & $\begin{array}{l}\text { Nilai } \\
\text { Tertinggi }\end{array}$ & $\begin{array}{l}\text { Rata- } \\
\text { Rata }\end{array}$ & $\begin{array}{l}\text { Standar } \\
\text { Deviasi }\end{array}$ \\
& Awal & 22 & 1 & 15 & 7.00 & 3.83 \\
\multirow{2}{*}{ Kontrol } & Akhir & 22 & 27 & 66 & 45.91 & 10.92 \\
& Awal & 23 & 2 & 25 & 9.52 & 5.37 \\
\multirow{2}{*}{ Eksperimen } & Akhir & 23 & 37 & 69 & 52.65 & 8.19 \\
& & & & & &
\end{tabular}

Dalam Tabel 1 terlihat rata-rata kemampuan awal kelas eksperimen lebih tinggi dari pada kelas kontrol, yaitu rata-rata nilai tes awal kelas eksperimen 9.52 dan rata-rata nilai tes awal kelas kontrol 7.00 dengan selisih rata-rata yang yaitu 2.52. Setelah diberi tes akhir, dilakukan analisis kemampuan peserta didik dalam pemecahan masalah. Agar lebih jelas, perbedaan rata-rata kemampuan awal dan kemampuan akhir kelas eksperimen dan kelas kontrol dapat dilihat pada Gambar 1. 


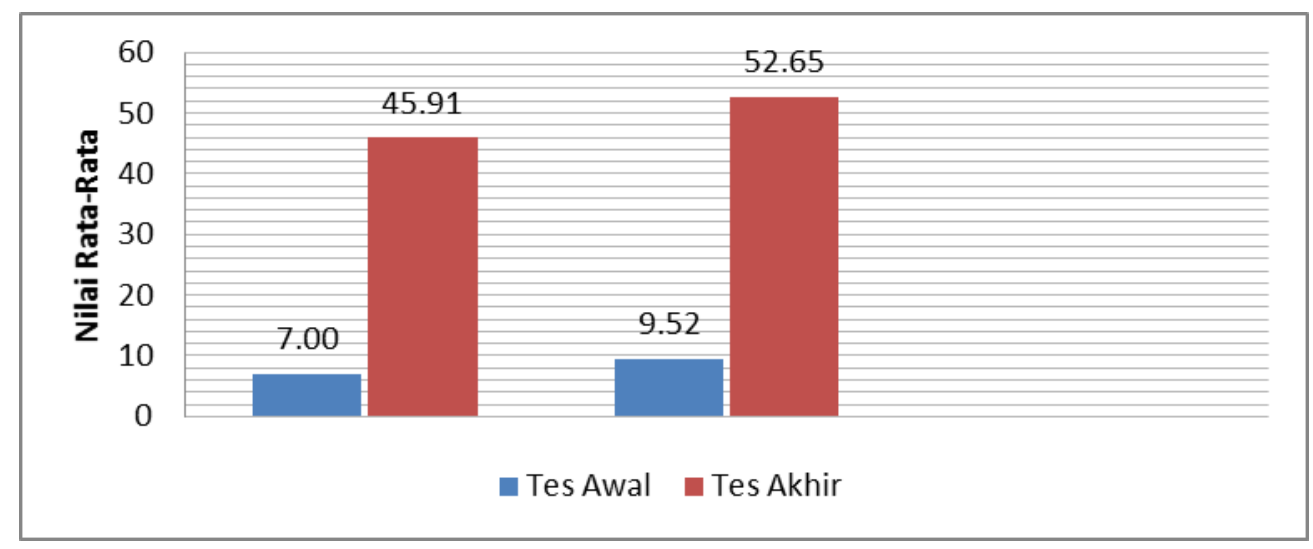

Gambar 1. Perbandingan Nilai Rata-Rata Tes Kemampuan Pemecahan Masalah

Berdasarkan Gambar 1, nilai rata-rata untuk kelas eksperimen meningkat dari 9.52 menjadi 52.65 dan untuk kelas kontrol meningkat dari 7.00 menjadi 45.91. Kelas eksperimen mengalami peningkatan sebesar 43.13 sedangkan kelas kontrol meningkat sebesar 38.91. Selain itu, terlihat perolehan nilai tertinggi maupun terendah pada kedua kelas mengalami peningkatan yang signifikan. Berdasarkan hasil tersebut, peningkatan rata-rata kemampuan pemecahan masalah peserta didik lebih tinggi di kelas eksperimen.

Uji prasyarat analisis merupakan syarat yang harus dipenuhi sebelum melakukan uji hipotesis. Uji prasyarat analisis terdiri dari uji normalitas data dan homogenitas data. Uji prasyarat kemampuan pemecahan masalah dilakukan dengan menggunakan data tes awal dan tes akhir yang diberikan pada kelas kontrol dan kelas eksperimen. Uji normalitas data dilakukan untuk menentukan jenis statistik yang digunakan. Selain itu, uji normalitas juga berfungsi untuk mengetahui normal atau tidak normal data kelas eksperimen dan data kelas kontrol. Hasil uji normalitas data tes awal dan tes akhir kemampuan pemecahan masalah untuk kelas eksperimen

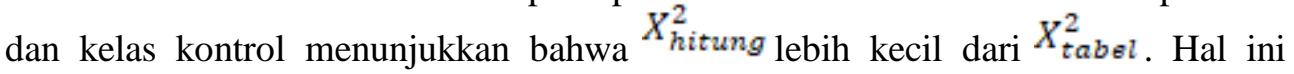
berarti data penelitian berasal dari populasi yang terdistribusi normal. Berdasarkan hasil tersebut, statistik yang digunakan adalah statistik parametrik. Uji homogenitas dihitung dengan menggunakan uji $\mathrm{F}$ dengan membandingkan nilai varians terbesar dan terkecil. Hasil uji homogenitas tes awal dan tes akhir kemampuan pemecahan masalah peserta didik kelas kontrol dan kelas eksperimen diperoleh $F_{\text {hitung }}<F_{\text {tabel }}$. Berdasarkan kriteria pengambilan keputusan, maka kedua sampel berasal dari populasi yang homogen.

Tes kemampuan pemecahan masalah yang diberikan adalah tes tertulis berbentuk uraian yang terdiri dari 6 soal. Kemampuan yang diukur adalah kemampuan pemecahan masalah yang terdiri dari 4 indikator. Kemampuan pemecahan masalah peserta didik sebelum diberikan perlakuan terlihat dari nilai tes awal (pre-test) dan kemampuan pemecahan masalah setelah diberikan perlakuan terlihat dari nilai tes akhir (post-test). Data kemampuan awal yang digunakan dalam penelitian ini adalah data hasil dari tes awal (pre-test) peserta sebelum diberikan 
perlakuan. Nilai tertinggi pada kelas eksperimen adalah 25, sedangkan nilai tertinggi pada kelas kontrol adalah 15. Nilai terendah pada kelas eksperimen adalah 2 , sedangkan nilai terendah pada kelas kontrol adalah 1 . Rata-rata nilai tes awal kelas eksperimen dan kelas kontrol masih pada kategori rendah.

Data kemampuan akhir yang diperoleh pada penelitian ini adalah data setelah diberikan perlakuan. Tes akhir diberikan untuk mengetahui homogenitas, normalitas, dan hipotesis penelitian. Nilai tertinggi pada kelas eksperimen adalah 69, sedangkan nilai tertinggi pada kelas kontrol adalah 66. Nilai terendah pada kelas eksperimen adalah 30, sedangkan nilai terendah pada kelas kontrol adalah 27. Ratarata nilai kelas eksperimen dan kelas kontrol adalah 52.65 dan 45.91. Hasil tes akhir pada kelas eksperimen dan kelas kontrol mengalami peningkatan dibandingkan dengan nilai pre-test dari segi nilai tertinggi, nilai terendah, dan nilai rata-rata.

Uji hipotesis dilakukan dengan uji-t. Data yang diuji adalah data peningkatan kemampuan pemecahan masalah fisika peserta didik pada kelas eksperimen dan kelas kontrol. Hasil olah data kemampuan pemecahan masalah menunjukkan bahwa $\mathrm{H}_{0}$ ditolak karena nilai $\mathrm{t}_{\text {hitung }}>\mathrm{t}_{\text {tabel. }}$. Hasil nilai $\mathrm{t}_{\text {hitung }}$ dapat dilihat pada Tabel 2 .

Tabel 2 Independent T-Test Kemampuan Pemecahan Masalah

\begin{tabular}{llllll}
\hline Kelas & $\overline{\mathbf{X}}$ & $\begin{array}{l}\text { Standar } \\
\text { Deviasi }\end{array}$ & T hitung & T tabel & Kriteria \\
\hline Eksperimen & 52.65 & 8.61 & 2.18 & 2.02 & $\mathrm{H}_{0}$ ditolak \\
\hline Kontrol & 45.91 & 11.98 & 28 & & \\
\hline
\end{tabular}

Berdasarkan Tabel 2 dapat disimpulkan bahwa terdapat pengaruh penggunaan model pembelajaran generatif dengan guided teaching technic terhadap kemampuan pemecahan masalah fisika peserta didik.

\section{B. Pembahasan}

Penelitian ini dilaksanakan di MA Al-Falah Pancordao Lombok Tengah tahun ajaran 2017/2018 dengan menggunakan dua kelompok sampel sebagai kelas kontrol dan eksperimen yang bertujuan untuk: Mengetahui pengaruh model pembelajaran generatif dengan guided teaching technic terhadap kemampuan pemecahan masalah fisika kelas XI.

Sampel penelitian terdiri dari dua kelompok, yaitu kelas XI MIPA 1 sebagai kelas eksperimen yang diajarkan atau diberikan perlakuan menggunakan model pembelajaran generatif dengan guided teaching technic dan kelas XI MIPA 2 yang diajarkan menggunakan model pembelajaran direct instruction. Kedua kelas mendapatkan pengajar yang sama yaitu dalam hal ini peneliti sendiri, materi ajar yang sama yaitu alat-alat optik, dan jumlah waktu pembelajaran yang sama yaitu empat kali pertemuan. Kedua kelas sebelum diberikan perlakuan terlebih dahulu diberikan tes awal dengan tujuan untuk mengetahui kemampuan awal peserta didik, dan setelah perlakuan diberikan tes akhir dengan tujuan untuk melihat peningkatan kemampuan pemecahan masalah fisika peserta didik. Rokhmat (2017) menyatakan bahwa pemecahan masalah diartikan atau dimaknai sebagai kemampuan yang menggunakan knowledge yang dimiliki. Artinya setiap masalah yang ada akan memicu seseorang untuk memikirkan solusi dari permasalahan tersebut. Menurut 
Azizah et al. (2016) menyatakan bahwa kemampuan pemecahan masalah memerlukan suatu keterampilan dan kemampuan khusus yang dimiliki masingmasing, yang mugkin akan berbeda antar dalam menyelesaikan suatu masalah. Perbedaan antara yang memiliki kemampuan rendah dan tinggi dalam pemecahan masalah fisika adalah bagaimana mengorganisasi dan menggunakan pengetahuan, serta menghubungkan satu konsep dengan konsep yang lain ketika memecahkan masalah [14].

Menurut Sujarwanto et al, (2014) menyatakan bahwa kemampuan pemecahan masalah adalah kemampuan seseorang untuk menemukan solusi melalui suatu proses yang melibatkan pemerolehan dan pengorganisasian informasi. Adapun indikator-indikator yang digunakan dalam kemampuan pemecahan masalah yang digunakan dalam penelitian ini ada empat, yaitu: (1) Mengenali masalah; (2) Merencanakan strategi; (3) Menerapkan Strategi; (4) Mengevaluasi solusi [15].

Kemampuan pemecahan masalah bertujuan untuk mengukur kemampuan peserta didik dalam menjawab soal-soal kognitif yang mencakup 6 indikator yaitu C1 sampai C6 yang di berikan kepada kedua kelas. Kemampuan pemecahan masalah yang digunakan terdiri dari empat indikator yaitu mengenali masalah, merencanakan strategi, menerapkan strategi dan mengevaluasi solusi. Pemilihan indikator disesuaikan dengan materi alat-alat optik, sehingga peseta didik memiliki waktu yang cukup dalam mengerjakan soal.

Uji instrumen dilakukan di SMA Al-Azhar NW Kayangan pada kelas XI MIPA 1 dengan jumlah peserta didik sebanyak 22 orang. Uji instrumen dilakukan terlebih dahulu sebelum memulai penelitian dengan tujuan untuk mengetahui tingkat validitas, reliabilitas, daya beda, dan tingkat kesukaran dari instrumen. Instrumen penelitian terdiri dari 6 item soal uraian yang dibuat berdasarkan indikator kemampuan pemecahan masalah peserta didik.

Hasil analisis uji instrumen kemampuan pemecahan masalah menggunakan soal uraian diperoleh bahwa semua item soal dikatakan valid. Soal-soal uraian yang sudah valid mewakili indikator kemampuan pemecahan masalah yang masingmasing mewakili indikator kemampuan pemecahan masalah yang digunakan dalam penelitian. Tingkat reliabilitas semua item soal uraian termasuk ke dalam kategori reliabel, karena nilai $r_{11}$ yang diperoleh lebih besar dari $r_{\text {tabel }}$. Tingkat daya beda item soal uraian yang didapatkan terdiri dari 3 item soal termasuk dalam kategori cukup yaitu nomor 1, 2 dan 3; 3 item soal termasuk ke dalam kategori baik yaitu nomor 4, 5, dan 6 . Penentuan kategori tingkat daya beda item item soal didasarkan jika DP $\leq 0,00$ termasuk kategori sangat jelek; $0,00<\mathrm{DP} \leq 0,20$ termasuk kategori jelek; $0,20<\mathrm{DP} \leq 0,40$ termasuk kategori cukup; dan $0,40<\mathrm{DP} \leq 0,70$ termasuk kategori baik. Tingkat kesukaran soal yang didapatkan terdiri dari 6 item soal termasuk dalam kategori mudah yaitu nomor 1, 2, 3, 4, 5, dan 6. Berdasarkan hasil analisis instrumen kemampuan pemecahan masalah untuk soal uraian diambil kesimpulan 6 item soal dapat dijadikan instrumen soal pada tes awal dan tes akhir keterampilan generik sains peserta didik.

Pada penelitian ini, sebelum diberi perlakuan pada peserta didik, terlebih dahulu dianalisis prestasi akademik yang dimiliki peserta didik dengan melihat hasil ulangan mid semester gasal dan melakukan tes awal sebagai acuan dalam pembagian kelompok dan menguji homogenitas untuk mengetahui kemampuan 
awal peserta didik. Hasil analisis tes awal menunjukkan bahwa tidak terdapat perbedaan yang signifikan antara kemampuan awal peserta didik kelas eksperimen maupun kelas kontrol. Nilai rata-rata yang diperoleh peserta didik dari hasil tes awal tergolong rendah, dimana nilai rata-rata kelas eksperimen dan kelas kontrol berturut-turut adalah 7.00 dan 9.52 .

Hasil mid semester tersebut dianalisis uji prasyarat yaitu uji homogenitas yang bertujuan untuk mengetahui apakah pasangan kelompok data yang diuji memiliki varian yang tergolong homogen atau tidak. Hasil uji homogenitas dimana $\mathrm{F}_{\text {hitung }}<\mathrm{F}_{\text {tabel }}$ pada taraf signifikan 5\%. Hal ini berarti kedua kelas homogen, atau peserta didik pada kedua kelas memiliki kemampuan awal yang sama.

Setelah dianalisis kemampuan awal, peserta didik diberi perlakuan berupa pembelajaran fisika dengan menggunakan model pembelajaran generatif dengan teknik guided teaching untuk kelas eksperimen dan pembelajaran konvensional untuk kelas kontrol dan dilanjutkan dengan memberikan tes akhir (post-test). Uji prasyarat yaitu uji homogenitas dan uji normalitas diberlakuan untuk tes akhir kedua kelas sampel. Uji homogenitasnya menunjukkan bahwa kedua sampel adalah homogen. Uji normalitas dilakukan untuk mengetahui data tes akhir kedua sampel terdistribusi normal atau tidak. Uji normalitas ini merupakan syarat yang harus terpenuhi sebelum melakukan uji hipotesis. Hasil uji normalitas penguasaan konsep pada kedua kelas diperoleh bahwa kedua kelas memiliki $\chi_{\text {hitung }}^{2}<\chi_{\text {tabel }}^{2}$ pada taraf signifikan 5\% sehingga kedua kelas terdistribusi normal. Karena hasil uji prasayarat tes akhir termasuk kategori homogen dan terdistribusi normal, maka dapat dilanjutkan dengan uji statistik parametrik sebagai uji hipotesis.

Berdasarkan hasil uji hipotesis yang dilakukan menggunakan uji-t satu pihak dengan persamaan t-test polled varians untuk mengetahui ada tidaknya pengaruh dengan membandingkan rata-rata nilai tes akhir dua kelas, maka diperoleh nilai $\mathrm{t}_{\text {hitung }}$ lebih besar dari $\mathrm{t}_{\text {tabel }}$ pada taraf signifikan 5\%, sehingga $\mathrm{H}_{0}$ ditolak dan $\mathrm{H}_{\mathrm{a}}$ diterima. Hal ini menunjukkan bahwa terdapat pengaruh model pembelajaran generatif dengan teknik guided teaching terhadap kemampuan pemecahan masalah fisika kelas XI tahun ajaran 2018/2019.

Model pembelajaran generatif dengan teknik guided teaching memeliki pengaruh terhadap kemampuan pemecahan masalah peserta didik. Terlihat pada tabel hasil tes akhir peserta didik bahwa rata-rata nilai ekperimen yang diberikan perlakuan memiliki nilai lebih tinggi dibandingkan kelas kontrol yang tidak di berikan perlakuan yang mengidentifikasikan bahwa model pembelajaran generatif dengan teknik guided teaching lebih unggul. Hasil dari kedua kelas sudah memenuhi harapan karena nilai kedua kelas lebih tinggi dari tes awal. Nilai tes akhir untuk kelas eksperimen dan kelas kontrol secara berturut-turut adalah 45.91 dan 52.65 .

Hal ini disebabkan karena terdapat perbedaan yang mendasar dalam sintak pembelajaran, dimana pada model pembelajaran generatif dengan teknik guided teaching, guru memberikan kesempatan kepada peserta didik untuk menguasai materi dengan malakukan percobaan disertai diskusi kelompok sehingga peserta didik dapat menjelaskan dengan mudah. Sedangkan pada pembelajaran konvensional peserta didik dituntut untuk memahami materi yang disampaikan ataupun dengan demonstrasi yang dilakukan guru didepan kelas. Selain itu, menurut 
peneliti peserta didik di kelas XI MA Al-Falah Pancordao belum dapat bertanggung jawab sepenuhnya terhadap persoalan yang diberikan. Peserta didik masih memerlukan bimbingan dari guru untuk menguasai materi pelajaran.

Hal ini sesuai dengan pendapat Sundayana et al. (2007) dan Sharfina (2017) yang menyatakan bahwa model pembelajaran generatif adalah pembelajaran aktif berpartisipasi dalam proses belajar dan dalam mengkonstruksi makna dari informasi yang ada disekitarnya berdasarkan pengetahuan awal dan pengetahuan yang dimiliki. Dengan terlibat secara langsung dalam memecahkan masalah selama proses pembelajaran peserta didik dapat menguasai materi dan konsep-konsep selama pembelajaran dengan baik [16-17]. Hal ini juga diperkuat dengan hasil penelitian sebelumnya mengenai model pembelajaran generatif dengan teknik guided teaching, yaitu menurut Tuada (2017) menyatakan bahwa model pembelajaran generatif dengan teknik guided teaching berpengaruh positif terhadap keterampilan proses sains peserta didik. Hal ini juga sangat berpengaruh dalam kemampuan pemecahan masalah peserta didik MA Al-Falah Pancordao dengan menggunakan model pembelajaran generatif dengan teknik guided teaching peserta didik lebih aktif dan dapat menyelesaikan masalah yang di berikan oleh peneliti. Berdasarkan penelitian yang telah dilakukan oleh Sugiana et al, (2016) telah terbukti bahwa pembelajaran fisika dengan menggunakan model pembelajaran generatif berpengaruh positif untuk mengaktifkan peserta didik dalam proses pembelajaran di dalam kelas. Dalam model pembelajaran generatif diperlukan keaktifan peserta didik, dalam hal ini adalah menjawab pertanyaan dari guru. Ekaputri (2016:59) menyatakan bahwa peserta didik diharapkan dapat menghubungkan pengetahuan baru dengan pengetahuan yang sudah ada dengan melibatkan pengetahuan dan konsepsi awal yang akan menghasilkan pemaknaan dan pemahaman peserta didik dalam pembelajaran [6].

Berdasarkan penelitian di atas, hasil dari model pembelajaran generatif dengan guided teaching technic memiliki pengaruh positif dalam proses belajar mengajar. Hal ini karena model pembelajaran generatif dengan teknik guided teaching memiliki kelebihan antara lain: 1) Pembelajaran generatif memberikan peluang kepada peserta didik untuk belajar secara kooperatif; 2) Merangsang rasa ingin tahu siswa; 3) Pembelajaran generatif untuk meningkatkan kataerampilan proses; 4) Meningkatkan aktifitas belajar siswa, di antaranya dengan bertukar fikiran dengan siswa yang lainnya, menjawab pertannyaan dari guru, serta berani tampil untuk mempresentasikan hipotesisnya. Selain memiliki kelebihan, model pembelajaran generatif dengan teknik guided teaching memiliki kelemahan antara lain: memerlukan waktu yang relatif lama. model pembelajaran generatif dihawatirkan terjadi salah konsep bagi peserta didik oleh karena itu guru harus membimbing peserta didik dalam menggali pengetahuan dan mengevaluasi hipotesis peserta didik pada tahap tantangan setelah peserta didik malakukan presentasi. Sehingga peserta didik dapat memahami materi dengan benar, meskipun usaha menggali pengetahuan sebagian besar adalah dari peserta didik itu sendiri.

Kemampuan pemecahan masalah merupakan suatu hal yang penting dalam proses pembelajaran. Rendahnya kemampuan pemecahan masalah akan berpengaruh terhadap kemampuan peserta didik, baik dalam menjawab soal serta menerapkan dalam kehidupan sehari-hari. Tes Kemampuan pemecahan masalah 
yang digunakan berupa 6 soal uraian. Tes uraian memiliki kebihan antara lain: 1) Tidak memberi banyak kesempatan untuk berspekulasi atau untung-untungan; 2) Mendorong siswa untuk berani untuk mengemukakan pendapat serta menyusun dalam kalimat yang bagus; 3) Dapat diketahui sejauh mana siswa mendalami suatu masalah yang diteskan [17]. Setiap soal diberi skor antara 0-4, berdasarkan tingkat ketepatan peserta didik dalam menjawab soal. Kemudian dari skor akhir tersebut dapat dilihat tingkat kemampuan pemecahan masalah peserta didik.

Kendala-kendala yang dialami oleh peneliti khususnya saat melaksanakan pembelajaran di dalam kelas ialah kurang optimalnya dalam pengelolaan waktu. Kendala lainnya yaitu tidak terbiasanya peserta didik diberikan tanggung jawab berupa lembar kerja peserta didik. Peserta didik di MA AL-Falah Pancordao masih harus selalu dibimbing setiap mengalami kesulitan, sehingga dalam proses pembeajaran berlangsung membutuhkan waktu lebih dari yang sudah direncanakan. Kemudian, dalam pembentukan kelompok, tidak semua peserta didik bersedia dikelompokkan berdasarkan arahan guru karena hubungan sosial yang renggang antara peserta didik yang berkemampuan tinggi dengan peserta didik yang berkemampuan rendah menyebabkan beberapa peserta didik tidak berkenan jika mereka dikelompokkan dalam satu tim yang sama. Sehingga dalam proses pembelajaran kadang peserta didik sering menyampaikan keluhannya terhadap teman kelompoknya kepada guru.

Terlepas dari segala kekurangan dalam penelitian ini, peneliti membuktikan bahwa model pembelajaran Generatif dengan Teknik Guided Teaching berpengaruh terhadap kemampuan pemecahan masalah fisika kelas XI, terbukti dari hasil uji hipotesis yang telah dilakukan. Oleh karena itu, model pembelajaran model pembelajaran Generatif dengan guided teaching technic dapat dijadikan alternatif untuk meningkatkan kemampuan pemecahan masalah.

\section{SIMPULAN DAN SARAN}

Berdasarkan hasil penelitian, analisis data dan pembahasan, maka dapat diambil kesimpulan: Model pembelajaran generatif dengan teknik guided teaching berpengaruh terhadap kemampuan pemecahan masalah fisika peserta didik. Adapun saran yang dapat diberikan bagi guru fisika adalah model pembelajaran generatif dengan teknik guided teaching dapat dijadikan alternatif strategi pembelajaran yang dapat diterapkan. Namun, dalam penerapannya memerlukan perencanaan dan persiapan yang matang sebelum diterapkan dikelas agar proses pembelajaran dapat berjalan sesuai dengan tujuan pembelajaran yang hendak dicapai.

\section{DAFTAR PUSTAKA}

[1] Arikunto, S. 2013. Dasar-Dasar Evaluasi Penelitian. Jakarta: PT Bumi Aksara.

[2] Azizah, R., Yuliati, L., dan Latifah, E. 2016. Kemampuan Pemecahan Masalah Melalui Pembelajaran Interactive Demonstration Siswa Kelas X SMA Pada Materi Kalor. Jurnal Pendidikan Fisika dan Teknologi. 2 (2): 5560. 
[3] Ekaputri, Y. N. 2016. Pegaruh Model Pembelajaran generatif Terhadap Pemahaman Konsep Siswa Kelas VIII Mts Di Kabupaten Pesisir selatan. Jurnal Pendidikan Matematika. 1 (1): 57-64.

[4] Gumilar, G. 2015. Pengaruh Model Pembelajaran Aktif Guided Teaching Terhadap Hasil Belajar Siswa Pada Standar Kompetensi Merekam Audio Distudio Di SMKN 2 Surabaya. Jurnal Pendidikan Teknik Elektro. 4 (2): 633-638.

[5] Huda, M. 2016. Model-Model Pengajaran danPembelajaran. Yogyakarta: Pustaka Pelajar.

[6] Rokhmat, J. 2017. Fisika Dasar. Mataram: Arga Puji Press.

[7] Sahidu, C. 2016. Evaluasi Pembelajaran Fisika. Mataram: Arga Puji Press Mataram

[8] Setyosari, P. 2015. Teknik Penelitian Pendidikan dan Pengembangan. Jakarta: Prenada Media Group.

[9] Sharfina., Halim, A., dan Safitri, R. 2017. Pengaruh Pembelajaran Generatif Terhadap Peningkatan Keterampilan Proses sains Siswa Kelas X SMA Negri 1 Kuala. Jurnal Pendidikan Sains. 5 (1): 102-106.

[10] Sugiana, I. N., Harjono, A., Sahidu, H. \& Gunawan. 2016. Pengaruh Model Pembelajaran Generatif Berbantuan Media Laboratorium Virtual Terhadap Penguasaan Konsep Fisika Siswa pada Materi Momentum dan Impuls. Jurnal Pendidikan Fisika dan Teknologi. 2 (2): 61-65.

[11] Sugiyono. 2016. Statistika untuk Penelitian. Bandung: Alfabeta.

[12] _. 2017. Statistika untuk Penelitian. Bandung: Alfabeta.

[13] Sujarwanto, E., Hidayat, A., Wartono. 2014. Kemampuan Pemecahan Masalah Fisika Pada Modeling Instruction Pada Siswa Kelas XI. Jurnal Pendidikan IPA Indonesia. 3 (1): 65-78.

[14] Sundayana, R. 2014. Statistika Penelitian Pendidikan. Bandung : Alfabeta.

[15] Tuada, R. N., Gunawan., dan Susilawati. 2017. Pengaruh Model Pemeblajaran Generatif Dengan Teknik Guided Teaching Terhadap Keterampilan Proses Sains. Jurnal Pendidikann dan Teknologi. 3 (2): 128136.

[16] Wena, M. 2014. Strategi Pembelajaran Inovatif Kontemporer. Jakarta: Bumi Aksara.

[17] Zulkarnain, I., Rahmawati, A. 2014. Model Pembelajaran Generatif Untuk Membangankan Kemampuan Penalaran Matematis Siswa. Jurnal Pendidikan Matematika. 2 (1): 9-14. 